\title{
Publisher Correction: Recent progress and perspectives of space electric propulsion systems based on smart nanomaterials
}

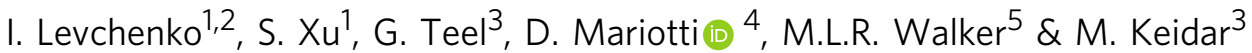

Correction to: Nature Communications https://doi.org/10.1038/s41467-017-02269-7; published online 28 February 2018

The original PDF version of this Article had an incorrect volume number of ' 8 '; it should have been ' 9 '. This has been corrected in the PDF version of the Article. The HTML version was correct from the time of publication.

Published online: 10 April 2018

\begin{abstract}
(c) (i) Open Access This article is licensed under a Creative Commons Attribution 4.0 International License, which permits use, sharing, adaptation, distribution and reproduction in any medium or format, as long as you give appropriate credit to the original author(s) and the source, provide a link to the Creative Commons license, and indicate if changes were made. The images or other third party material in this article are included in the article's Creative Commons license, unless indicated otherwise in a credit line to the material. If material is not included in the article's Creative Commons license and your intended use is not permitted by statutory regulation or exceeds the permitted use, you will need to obtain permission directly from the copyright holder. To view a copy of this license, visit http://creativecommons.org/licenses/by/4.0/.
\end{abstract}

(c) The Author(s) 2018

\footnotetext{
${ }^{1}$ Plasma Sources and Applications Centre, National Institute of Education, Nanyang Technological University, 1 Nanyang Walk, Singapore 637616, Singapore. ${ }^{2}$ School of Chemistry, Physics, and Mechanical Engineering, Queensland University of Technology (QUT), 4000 Brisbane, QLD, Australia. ${ }^{3}$ Department of Mechanical and Aerospace Engineering, The George Washington University, Washington, DC 20052, USA. ${ }^{4}$ Nanotechnology and Integrated Bio-

Engineering Centre (NIBEC), Ulster University, BT37 OQB Newtownabbey, UK. ${ }^{5}$ School of Aerospace Engineering, Georgia Institute of Technology, Atlanta, GA, USA. Correspondence and requests for materials should be addressed to I.L. (email: levchenko.igor@nie.edu.sg)
} 